371.3::[821.163.41-14:398

371.671:811.163.41

https://doi.org/10.18485/kij.2020.67.2.11

ВЛАДИМИР Б. МИЛОЈЕВИЋ

XIV београдска гимназија

Београд
Оригинални научни рад

Примљен: 20.10.2020.

Прихваћен: 14.12.2020.

\title{
ТЕКСТ НАРОДНЕ ЕПСКЕ ПЕСМЕ РОПСТВО ЈАНКОВИЋА СТОЈАНА У ЧИТАНКАМА ЗА ОСНОВНУ И СРЕДЬУ ШКОЛУ
}

\begin{abstract}
У раду је провераван текст народне епске песме Ропство Јанковића Стојана у осам читанки за седми разред основне школе и седам читанки намењених ученицима првог разреда средње школе. У сваком од уџбеника уочена су (не)знатна одступања текста песме у односу на њен оригинални (изворни) облик. Грешке су у раду класификоване по томе колико се од оригиналног записа разликују по наслову, затим по испису старога гласа jam, одступању од десетерачког стиха, употреби сугласника $x$ и $j$, као и по лексичким и интерпункцијским неправилностима. На крају се констатује у којим је уџбеницима забележен најмањи, тј. највећи број одступања.
\end{abstract}

Кључне речи: народна песма, читанка, уџбеник, основна школа, средња школа.

\section{1. Увод}

Међу епским народним песмама средњих времена које припадају тематском кругу о ускоцима као најпознатије издвајају се Иво Сенковић и ага од Рибника и Ропство Јанковића Стојана за коју се везује интернационални епски мотив о мужу на свадби своје жене. Ова песма обрађује се и у основној и у средњој школи (у седмом разреду основне, а потом у првом разреду средње школе). У наставним плановима и програмима нашег предмета није необично да се иста књижевна дела у основној школи обрађују у одломку, док се у средњој школи читају и анализирају у целини. Пример за то је Његошев Горски вијенаи или Сеобе Милоша Црњанског. Није необично ни то да иста књижевна дела ученици обрађују два пута у току школовања - најпре у вишим разредима основне шко-

\footnotetext{
*vlade.milojevic@yahoo.com
} 
ле, а потом и у средњој школи. Такав је случај са Бојићевом Плавом гробницом, народном лирском песмом Српска дјевојка, народним епском песмом Диоба Јакшића итд.

Разумљиво је да се исто књижевно дело анализира са извесним разликама у односу на узраст ученика. С тим у вези, дидактичко-методичка апаратура у читанкама морала би нужно бити прилагођена 'зрелости' ученика. Оно што би пак требало да је неспорно јесте чињеница да текст књижевног дела не би смео имати било каквих одступања у различитим уџбеницима, без обзира на то ко их потписује као издавач или аутор. Та би чињеница требало да се односи на сва књижевна дела у читанкама, свеједно да ли она припадају народној или ауторској књижевности, да ли су дата у одломку или у целини.

У којој мери се текст ове епске песме (не)подудара са оригиналним (изворним) текстом штампаним у трећој књизи Српских народних пјесама Вука Караџића (Караџић 1976: 124-127) проверавали смо у укупно 15 читанки (8 за основну и 7 за средњу школу). Уџбенике је издало 6 издавачких кућа. Потписује их укупно 28 аутора, а на процени њиховог квалитета радило је нешто више од 50 рецензената (Табела 1$){ }^{1}$

Табела 1. Читанке за седми разред основне и први разред средње школе

\begin{tabular}{|c|c|c|}
\hline Издавач: & $\begin{array}{l}\text { Основна школа } \\
\text { (седми разред): }\end{array}$ & $\begin{array}{c}\text { Средња школа' } \\
\text { (први разред): }\end{array}$ \\
\hline \multirow[t]{2}{*}{$\begin{array}{c}\text { Завод за } \\
\text { Уџбенике }\end{array}$} & М. Андрић, 2009: & $\begin{array}{l}\text { Љ. Николић и Б. Милић, } \\
\text { 2010: } \\
\text { Читанка са књижевнотео- } \\
\text { ријским појмовима } \\
\text { за І разред средње школе }\end{array}$ \\
\hline & $\begin{array}{l}\text { ПЛАВО И ЗЛАТНО } \\
\text { Читанка за седми разред } \\
\text { основне школе }\end{array}$ & $\begin{array}{l}\text { Б. Милић и К. Вучић, 2016: } \\
\text { Читанка са кюижевнотео- } \\
\text { ријским појмовима } \\
\text { за І разред гимназија и } \\
\text { средюих стручних школа }\end{array}$ \\
\hline
\end{tabular}

${ }^{1}$ Од школске 2019/2020. године одобрење школских власти имају 4 читанке за први разред средње школе. То је читанка коју у издању Завода за уџбенике као аутори потписују Б. Милић и К. Вучић, затим читанка чији су аутори М. Павловић и 3. Мркаљ (Klett), као и уџбеници које су издали Бигз и Нови Логос. 


\begin{tabular}{|c|c|c|}
\hline Klett & $\begin{array}{l}\text { Н. Станковић Шошо, 2009: } \\
\text { РИЗНИЦА РЕЧИ } \\
\text { Читанка за седми разред } \\
\text { основне школе }\end{array}$ & $\begin{array}{l}\text { М. Павловић, 2012: } \\
\text { Читанка за први разред гим- } \\
\text { назија } \\
\text { и средюих стручних икола }\end{array}$ \\
\hline & $\begin{array}{l}\text { 3. Несторовић и 3. Груша- } \\
\text { новић, 2016: } \\
\text { ПУТ } \\
\text { Читанка за седми разред } \\
\text { основне школе }\end{array}$ & $\begin{array}{l}\text { М. Павловић и З. Мркаљ, } \\
\text { 2019: } \\
\text { Читанка за први разред гим- } \\
\text { назије }\end{array}$ \\
\hline \multirow[t]{2}{*}{$\begin{array}{l}\text { Нови } \\
\text { Логос }\end{array}$} & $\begin{array}{l}\text { О. Радуловић, 2009: } \\
\text { ЈЕЗИК ЈЕ ДРВО ЖИВОТА } \\
\text { Читанка за седми разред } \\
\text { основне школе }\end{array}$ & $\begin{array}{l}\text { Н. С. Шошо, Б. Сувајџић и } \\
\text { С. Петаковић, 2014: } \\
\text { Читанка за први разред гим- } \\
\text { назија и } \\
\text { средюих стручних школа }\end{array}$ \\
\hline & $\begin{array}{l}\text { Н. С. Шошо и Б. Сувајшић, } \\
\text { 2012: } \\
\text { УМЕТНОСТ РЕЧИ } \\
\text { Читанка за седми разред } \\
\text { основне школе }\end{array}$ & \\
\hline Едука & $\begin{array}{l}\text { Г. Влаховић и Ј. Влаховић, } \\
\text { 2014: } \\
\text { Читанка за седми разред } \\
\text { основне школе }\end{array}$ & $\begin{array}{l}\text { А. Стишовић Миловановић, } \\
\text { О. Радуловић и В. Живко- } \\
\text { вић, 2012: } \\
\text { Читанка за први разред гим- } \\
\text { назија и средњих школа }\end{array}$ \\
\hline Бигз & $\begin{array}{l}\text { С. Костадиновић, 3. Гру- } \\
\text { шановић и } \\
\text { Ј. Ракић Каменица, 2015: } \\
\text { Читанка српског језика за } \\
\text { седми разред основне школе }\end{array}$ & $\begin{array}{l}\text { Душко Бабић, 2010: } \\
\text { Читанка за први разред } \\
\text { средюе школе }\end{array}$ \\
\hline $\begin{array}{c}\text { Креативни } \\
\text { центар }\end{array}$ & $\begin{array}{l}\text { С. Маринковић и С. Мар- } \\
\text { ковић, 2009: } \\
\text { Читанка за седми разред } \\
\text { основне школе }\end{array}$ & \\
\hline
\end{tabular}




\section{2. Песма у наставним програмима}

Да је ова епска песма постојала у наставним плановима и програмима још након Другог светског рата, сазнајемо из студије М. Дашића Народна књижевност у наставним плановима и програмима (Дашић 2016: 29, 32).

Актуелни наставни програм бележи да се у седмом разреду основне школе обрађују епске народне песме о хајдуцима и ускоцима (избор), док се у програму за први разред средње школе у оквиру овог тематског круга наводи и наслов народне епске песме Ропство Јанковића Стојана.

Чињеница да се проучавање народне књижевности готово завршава са првим разредом средње школе, тј. да се након тога не обрађује ниједна народна епска или лирска песма, свакако се може сматрати једном од значајнијих мањкавости наставних програма.

\section{3. Песма у читанкама}

О важности читанке као уџбеника намењеног ученицима и наставницима наилазимо на честе потврде у стручној литератури. „Читанка је један од два основна уџбеника за наставу Српског језика и књижевности. Тај уџбеник у систему образовања и васпитања има посебно место и он доноси првенствено књижевне текстове који су предвиђени наставним програмом за обраду у конкретном разреду” [...] (Брборић 2019: 113). „Она [читанка, прим. В. М.] истовремено мора да буде и поуздано средство на које ће се наставник ослонити приликом рада са одељењем на часу, али и учеников савезник у самосталном бављењу књижевним делима [...] Ваљана читанка поред поузданих текстова самих књижевних дела, заснованих, кад год је то могуће на критичким издањима, садржи и адекватну радну апаратуру" (Дашић 2016: 62). ${ }^{2}$ Слажемо се са ставом да је читанка од пресудног значаја за наставу књижевности, но примећујемо и то да у новије време, нарочито средњошколци, све више прибегавају читању књижевних текстова са интернета. Ученици на тај начин најчешће долазе до извора који нису поуздани, а почесто је у њима занемарена правописна и свака друга норма.

Познато је да су читанке далеко најобимнији уџбеници и тиме највише оптерећују школску торбу. Ученицима је једноставније да 'укуцају' одређени наслов и тако лако и брзо дођу до жељеног садржаја. Ипак, колико год да је интер-

\footnotetext{
${ }^{2}$ Објашњењима читанке као уџбеника могли бисмо додати и оно што бележи Обратни асоцијативни речник српскога језика у коме се наводи да је 5 испитаника у првој књизи Асоцијативног речника на стимуланс књижевност одговорило читанка, 4 испитаника је на стимуланс српски језик дало одговор читанка, 3 испитаника на стимуланс књига одговорило је читанка, док од појединачних одговора овај речник бележи то да је читанка испитаницима била асоцијација на следеће стимулансе: истина, катарза, оташбина, српски и српскохрватски (Драгићевић 2011: 687). Имајући у виду чињеницу да су испитаници у овом обимном истраживању били средњошколци и студенти, бићемо слободни да закључимо то како они дефинишу, тј. доживљавају читанку. Она је, по њиховом уверењу, књига у којој су садржани књижевни текстови на српском језику, претежно националних писаца, који треба да су истинити (тачни) и чији је циљ да читаоца оплемене.
} 
нет у свакодневном животу, па тако и у настави, постао неизоставан, мишљења смо да би маргинализовање уџбеника у наставном процесу било веома штетно. Уџбеник је, без сумње, важан део наставног процеса, све једно да ли је ученицима доступан у штампаном или у електронском облику.

Текст епске песме Ропство Јанковића Стојана проверавали смо у читанкама које се последњих година употребљавају у нашим школама и које су добиле одобрење за употребу од просветних власти. Неке од њих се користе у настави готово три деценије, док је већина релативно новијег датума. У свакој од читанки које смо консултовали песма је штампана у целини ћириличним писмом.

Чињеница је да су читанке појединих издавача далеко заступљеније у употреби, док се неке, које смо у раду консултовали, од скора више не користе. Напоменимо и то да Завод за уџбенике има две читанке за први разред средње школе, Нови Логос је издао две читанке за седми разред основне школе, док Klett у том смислу предњачи са дуплим уџбеницима и за седми и за први разред³. У не трако далекој прошлости постојала је по једна читанка за сваки разред. Данас се пак отишло у другу крајност. То што имамо велики број издавача читанки за исти разред сматрамо претераним и непотребним, посебно имајући у виду чињеницу да ће их ускоро бити и више. ${ }^{4}$

\section{4. Одступања од изворног текста песме у читанкама}

\section{1. Локализација текста}

Великим недостатком сматрамо то што ни једна читанка намењена основцима не наводи локализацију текста песме у смислу давања информације о томе одакле је песма преузета. Тек две средњошколске читанке наводе такав податак. ${ }^{5}$ Читанка коју су саставиле Б. Милић и К. Вучић, а коју је издао Завод за уџбенике, наводи извор: „Вук Стефановић Караџић, Српске народне пјесме VI, Просвета, Београд, 1988” (Милић 2010: 205). У читанци Новог Логоса коју као аутори потписују Н. С. Шошо, Б. Сувајџић и С. Петаковић такође се наводи извор: „Епске песме о хајдуц̧има и ускоцима, прир. Бошко Сувајџић, Београд:

${ }^{3}$ Појаву да једна издавачка кућа има по две читанке за исти разред или пак чињеницу да поједини аутори потписују две читанке истог разреда а различитог издавача, нећемо разматрати, јер то није премет овог рада.

${ }^{4}$ Од школске 2020/2021. године у нашим школама наћи ће се чак девет читанки намењених ученицима седмог разреда основне школе. Без намере да будемо саркастични, уколико „уџбеничка индустрија” настави да ради оваквом продуктивношћу, сматрамо да бисмо у не тако далекој будућности могли очекивати да свака школа, можда чак и сваки наставник, објаве сопствену читанку.

${ }^{5}$ Већина уџбеника садржи азбучник писача, неки и речник књижевнотеоријских појмова, индекс појмова, извор фотографија, репродукиија и сл. По нашем мишљењу, у њима би се морало пронаћи места и за информацију одакле је књижевно дело преузето.

${ }^{6}$ Овде је, по свој прилици, начињена омашка у нумерацији књиге Вукових Српских народних пјесама. Уместо броја VI требало би да стоји број III. 
Гутембергова галаксија, 2003” (Н. С. Шошо 2014: 210). Позитивно је то што се у овим уџбеницима наводи извор, али морамо констатовати и то да текст песме у њима ипак одступа од наведеног извора, у шта ћемо се уверити у овом раду.

\section{2. Наслов песме}

Да исправан наслов песме гласи Ропство Јанковића Стојана, тј. да презиме епског јунака има дужи облик „Јанковића”, а не „Јанковић”, бележи тек један уџбеник. ${ }^{7}$ Реч је о Читанции са књижевнотеоријским појмовима за први разред средње школе чији су аутори Љ. Николић и Б. Милић (Николић 2010: 190). Уочавамо и то да наслов песме у садржају овога уџбеника ипак гласи другачије - Ропство Јанковић Стојана (Николић 2010: 7). Нејасна је чињеница по којој готово све читанке доносе погрешан наслов ове песме. Осим треће књиге Српских народних пјесама Вука Стефановића Караџића (Караџић 1976: 123), исправан наслов песме бележе и друге познате антологије епских народних песама, од којих вреди поменути следеће: Антологија јуначких песама (Ђурић, 1990: 559), Српске народне епске песме и баладе (Милошевић Ђорђевић 2001: 364), Антологија епских народних песама (Самарџија 2005: 309) и Епске народне песме о хајдуцима и ускоцима (Сувајџић 2003: 213).

\section{3. Рефлекс гласа ,,јат”}

Песма Ропство Јанковића Стојана садржи 31 лексему са рефлексом старога гласа ,јат”. То су речи: бежимо, беседи (два пута), беседити, беле, беломе (три пута), гнездо (два пута), девера, доле, досети, колено, лепо (три пута), месеци (два пута), недеље (два пута), огрејало, остарела (два пута), побего, побегоше, попевати, разумео, речи, сећају, сутра. ${ }^{8}$ У оригиналном запису песме од наведених речи тек је 6 испевано ијекавицом, док су две дате на икавском изговору. То су стални епитети у стиховима: Ищетала пред дворе бијеле, / Иди, брате, двору бијеломе, / Од’ Илија двору бијеломе, / Брзо оде двору бијеломе, / Косу реже остарила мајка и Кад угледа остарила мајка. Именица гнездо у тужбалици Стојана Јанковића гласи гњиздо: Вила гњиздо тища ластавища, / Па jој не да гъиздо да развија (Караџић 1976: 123-127). Ипак, у уџбеницима је ситуација посве другачија. Тек четири читанке за седми разред основне школе доносе све тачне (оригиналне) облике речи са рефлексом ,јата”. То су уџбеници чији су издавачи Завод за уџбенике, Едука, Бигз и Креативни центар, док у осталим уџбеницима за седми разред и чак свим средњошколским констатујемо мање или веће недоследности приликом ијекавског исписа речи.

${ }^{7}$ И у старијим читанкама било је погрешног навођења наслова ове песме. М. Дашић примећује да је у Читанци за V разред гимназије Д. Вученова и Р. Димитријевића из 1959. године дошло до инверзије приликом навођења наслова ове песме, где он гласи Ропство Стојана Јанковића (Дашић 2016: 67).

${ }^{8}$ Речи су наведене азбучним редом у оном облику у коме су употребљене у песми. 
Најрадикалнији приступ ијекавизације песме, без сумње, срећемо у читанци за седми разред, коју у издању Новог Логоса као аутор потписује О. Радуловић. Овде су готово сви екавски облици речи преиначени на ијекавске - прецизно, 22 речи су ијекавизиране. Да тај посао ипак није спроведен доследно, доказују три стиха: Сутра јесте петак, турски светаи / Млађа љуба од недеље дана и Већ побего саду винограду. Нејасан је критеријум по коме су неке речи у овом уџбенику наведене тзв. ијекавским јотовањем (Млађа љуба од неђеље дана), док су друге пак дате ијекавским књижевним изговором (Отпусти се од ручна дјевера). Такође, и именица недеља двојако је третирана у различитим стиховима - у оном који припада народном певачу сусрећемо дијалекатски облик: Млађа љуба од неђеље дана. Међутим, када исти стих изговара лик из песме (Стојанова мајка), именица недеља задржава екавски облик: Млађа љуба од недеље дана. Ово је једина читанка у којој је именица гњиздо из познатих алегоријских стихова преиначена у облик гњездо - Вила гњездо тица ластавииа, / Па јој не да гњездо да развија. У овом уџбенику недостаје 147. стих Кад угледа остарила мајка (Радуловић 2009: 140-141).

Од свих речи из песме које садрже рефлекс ,јата”, у уџбеницима је најчешће ијекавизиран глагол беседити који је штампан ијекавским изговором у 5 читанки намењених седмацима и 3 средњошколске. Дакле, у 7 уџбеника овај глагол наведен је, у складу са извором, у екавском облику: Ал'беседи Смиљанић Илија, у 6 читанки гласи Ал' бесједи Смиљанић Илија, док обе средњошколске читанке у издању Завода за уџбенике доносе неправилан ијекавски облик глагола беседити, па у њима стих гласи: Ал'бјеседи Смиљанић Илија. Примећујемо и то да је исти глагол у свим уџбеницима задржао екавски облик у стиховима Поче Стојан тијо беседити и Беседи им Јанковић Стојане (изузетак је Читанка за седми разред основне школе О. Радуловић).

Приликом анализе ове песме, тешко је претпостави да бисмо ученицима, свеједно да ли су у питању основци или средњошколци, могли разјаснити то да један лик из песме бесједи или бјеседи, док други пак беседи.

Већ смо закључили да је највећи број речи са рефлексом ,,јата” ијекавизиран у основошколској читанци „Језик је дрво живота” у издању Новог Логоса. Далеко мањи број 'неоснованих' ијекавизама, укупно 4, бележимо у читанци „Ризница речи”, коју као аутор потписује Н. С. Шошо, док је по једна реч са екавског на ијекавски изговор преиначена у основошколским уџбеницима чији су наслови „Пут” и „Уметност речи”.

Обе читанке за средњу школу чији је издавач Klett доносе по 5 ијекавизама, супротно изворном тексту. То су речи: неђеље, бјежимо, кољено, разумио и рјечи 9 .

\footnotetext{
${ }^{9}$ Овде је лексема реч наведена са једносложном заменом ,,јата” као рјеч, највероватније због тога да не би дошло до нарушавања десетерачког стиха. Претпоставка је и то да се иста ситуација догодила приликом ијекавизације придева лепо у љепо (а не лијепо) у стиховима Лепо су га свати дочекали и Лепо Стојан свате даривао (Караџић 1976: 125-127).
} 
Средњошколска читанка у издању Новог Логоса садржи 4 ијекавизма који не припадају оригиналном запису песме - неђеље, мјесеци, бесједи и љепо, док је глагол из стиха Ал беседи Смиљанић Илија преиначен на ијекавицу у обе читанке Завода за уџбенике, као и у онима чији су издавачи Едука и Бигз. Епитет из стиха Кад угледа остарила мајка, 4 средњошколске читанке доносе с обликом остарела.

Када је посреди рефлекс гласа ,јат”, избројали смо тачно 50 речи које су у супротности са оригиналом песме - укупно их је 28 у четири основошколске читанке, док их је 10 мање у читанкама за први разред средње школе. Чињеница да у чак 11 уџбеника бележимо (не)велика одступања од оригиналног текста, по свој прилици, упућује на то да су се аутори уџбеника ослонили на непоуздане изворе. ${ }^{10}$

\section{4. Одступање од десетерца}

Једна од основних одлика епских народних песама јесте стих од десет слогова, тзв. епски десетерай који има паузу (цеезуру) након четвртог слога.

Нејасно је како се догодило то да неки уџбеници ову песму донесу са вишком слогова у неким стиховима или пак са 'окрњеним' десетерцем. У читанци за седми разред основне школе „Ризница речи” бележимо по 11 слогова у стиховима: Нађе мајку у своме винограду и Ко ће пред мене стару ишетати (Станковић Шошо 2009: 29-31). У читанци која носи наслов „Језик је дрво живота”, намењеној такође основцима, наилазимо на три стиха у којима је десетераи 'продужен' за један слог. То су стихови: Божија помоћ, сиротищо стара, / Кад је Стојан разумио ријечи и Ко ће пред мене стару ииетати (О. Радуловић: 2009: 140-141). Стихове од по 9 слогова бележимо у Читанци за први разред гимназија и средњих школа чији је издавач Едука. О стиховима из овог уџбеника Ја не мог' од јада гледати и Већ побег' саду винограду (Стишовић Миловановић 2012: 151) биће говора и касније.

\section{5. Сугласници $x$ и $j$}

Позната је чињеница да Вук Караџић глас $x$ није користио све до 1836. године, као и то да највећи део српских народних говора нема глас $x$ - он се губи или се замењује другим гласовима. Одсуство овога гласа готово је уобичајено у народној књижевности која је својим највећим делом настала на источнохерцеговачком дијалекту. Такав је случај и са овом епском песмом.

${ }^{10}$ Тешко је утврдити све изворе који су састављачима читанки могли послужити за преузимање песме. Примера ради, у комплету лектире за VII разред основне школе једног новосадског издавача налази се и збирка у којој је песма Ропство Јанковића Стојана. У њој смо, у готово трећини од укупног броја стихова, уочили различите неправилности у односу на оригинални запис, као и то да неки стихови недостају. Сматрамо срећном околношћу то што је ова песма у свим читанкама штампана у целини, сходно чињеници да смо у већини „лектира” (махом намењених основцима) наишли на далеко бројније и озбиљније пропусте неголи у уџбеницима. 
У читанци за седми разред чији ауторски тим чине С. Констандиновић, 3. Грушановић и Ј. Ракић Каменица једно $x$ је 'залутало' у стиху $У$ Стамбол их одведоше Турии. Необично је то што се у овом уџбенику истим речима (у различитим стиховима) приступа двојако када је посреди употреба гласа $x$. Тако један стих гласи У Стамбол их одведоше Турич, а други Тамо и је цุаре потурчио (Костадиновић 2015: 76). У средњошколској читанци аутора Д. Бабића ситуација је обрнута па исти стихови гласе: У Стамбол и одведоше Турцчи и Тамо их је изаре потурчио (Бабић 2010: 229). У осталим уџбеницима сугласник $x$ оправдано изостаје.

Сугласник ј недостаје у прилогу тијо у стиху Поче Стојан тијо беседити у двема читанкама за основну школу - једну, у издању Бигза, потписује трочлани ауторски тим, а другу, с насловом Уметност речи, саставили су Н. С. Шошо и Б. Сувајџић. Са друге стране, овај сугласник је сувишан у трима средњошколским читанкама, и то код узвика у стиху О Илија, да мој мили брате. Реч је о обе читанке у издању Завода за уџбенике и трећој, коју у издању Едуке потписује трочлани ауторски тим. У овој читанци већ смо констатовали нарушавање епског десетерца у стиховима: Ја не мог' од јада гледати и Већ побег' саду винограду (Стишовић Миловановић 2012: 151). Дакле, овде је осим оправданог изостајања сугласника $x$, 'неоправдано' изостао још и вокал $o$.

У Читанизи за први разред средње школе Душка Бабића глагол моћи је уместо у аористу наведен у облику презента, па стих Jа не мого од јада гледати, овде гласи Ја не могу од јада гледати (Бабић 2010: 230).

Укупно смо констатовали 10 грешака овог типа у 6 читанки. Одсуство гласова $x$ и $j$, у складу са текстом оригинала, доносе све читанке у стиховима Поараше дворе Јанковића, / Снае Јеле заборавит нећу; и Снао Јело, неномено злато.

\section{6. Лексичке и друге грешке}

Деминутив именице кољ јавља се два пута у песми и то у песничком облику коњиц. Најпре, када се Илија обраћа брату с идејом о бекству из турског ропства: Да узмемо два добра коњица, а потом, када народни приповедач потврђује да су браћа кренула пут роднога краја: Па узеше два добра коњица (Караџић 1976: 123-124). Нејасно је како су коњищи у неким уџбеницима преименовани у коњиће као што је то учињено у читанци „Језик је дрво живота” која је намењена основцима, а чији је аутор О. Радуловић. Није јаснија ни логика по којој је у неким уџбеницима облик ове именице употребљен двојако. Наиме, у говору епског јунака наведен је деминутив коњић, док у говору народног приповедача уочавамо оригинални (изворни) облик коњиц. Ово бележимо у двема читанкама - једној за основце „Ризница речи”, чији је аутор Н. С. Шошо и другој, намењеној ученицима средње школе, коју осим Н. С. Шошо као аутори потписују још Б. Сувајџић и С. Петаковић. 
Стих у коме Стојанова љуба препознаје мужа и о томе обавештава његову сестру, а своју заову, требало би да гласи: Ево m' браца, господара мога! (Караџић 1976: 125). Хипокористик брацца, који овде свакако има улогу да нагласи сестринску љубав према брату, у неким уџбеницима је преиначен у 'неутрални' облик брата. Поново је реч о основошколској читанци „Језик је дрво живота”, али и о две средњошколске у издању Kletta - старијој, чији је аутор М. Павловић и оној новијег датума за коју ауторство потписује још и 3. Мркаљ.

О братовљевој љубави према сестри сведоче стихови у којима Стојан казује: Стан'те, браћо, кићени сватови! / Док се мало сестрице нагледим (Караџић 1976: 125). Овде је споран презент глагола нагледити који је у готово свим средњошколским читанкама претворен у облик нагледати. Дакле, све читанке намењене средњошколцима (с изузетком оне у издању Новог Логоса) доносе погрешан облик овога глагола. У читанкама за основну школу ситуација је обрнута - нетачан облик овога глагола доноси једино читанка „Језик је дрво живота”.

Врхунац љубави између брата и сестре који се срећу након дугогодишње раздвојености опеван је стихом: Руке шире, у лица се љубе (Караџић 1976: 125). У готово свим средњошколским уџбеницима именица лища наведена је у облику једнине, те овај стих у њима гласи Руке шире, у лище се љубе (изузетак је читанка Завода за уџбенике чији су аутори Б. Милић и К. Вучић). Три уџбеника за седми разред основне школе доносе овај стих погрешно, с именицом у облику једнине. То су читанке које имају наслове „Ризница речи”, „Пут” и „Језик је дрво живота".

Као прилично учесталу грешку у средњошколским уџбеницима уочавамо неправилно употребљен род глагола допасти. Наиме, након што су из вишегодишњег ропства стигли у завичај, Илија поручује брату да ће најпре отићи у свој виноград, како би се уверио Ко га веже, ко ли га залама, / Коме ли је допао у руке (Караџић 1976: 124). Више од половине средњошколских читанки глагол допасти, уместо у мушком, наводи у средњем роду, па овај стих у њима гласи Коме ли је допало у руке. Реч је о обе читанке које је издао Завод за уџбенике и онима које као издавачи потписују Едука и Бигз.

Упитно-односну заменицу што из стиха $A$ што ћемо ми за наше благо (Караџић 1976: 125) три уџбеника намењена ученицима основне школе заменила су заменицом шта, те овај стих у њима гласи $A$ шта ћемо ми за наше благо. Ову грешку смо забележили у обе читанке које је издао Klett („Ризница речи” и „Пут”) и у трећој, у издању Едуке, чији су аутори Гордана и Јагош Влаховић.

У свим читанкама за седми разред и у већини средњошколских читанки споран је облик датива именице мајка, с краја песме, у стиху И говори својој старој мајки (Караџић 1976: 127). Само две читанке за први разред средње школе, обе у издању Kletta, бележе ову именицу без извршене сибиларизације. Да сви други уџбеници доносе ову именицу неправилно (са извршеном гласовном променом), проверавали смо у Правопису српскога језика, тачније у Речнику уз правопис где стоји: „мајка (дат. мајци, у знач. мати), нар. хип. мајка (дат. мајки, 
об. у знач. бака или свекрва” (Правопис 2010: 364). И Речник српскохрватскога књижевнога језика за именицу мајка предвиђа облик мајки када је посреди: „назив од мила за бабу (унучићима) и за свекрву или старију жену уопште" (Речник 1969: III, 275), што је овде свакако случај.

Две средњошколске читанке, обе у издању Kletta, прилог доле из стиха Она стрча доле низ чардаке, (Караџић 1976: 125) наводе у облику доли - Она стрча доли низ чардаке (Павловић 2012: 133 и Павловић, Мркаљ 2019: 153).

Укупно је 45 лексичких омашки у тексту песме у читанкама. Нешто већи број неправилности уочавамо у средњошколским уџбеницима, укупно 26, док смо у читанкама намењеним ученицима седмог разреда избројали 19 грешака. Највише уџбеника, чак 13, погрешно је донело датив именице мајка (са извршеном гласовном променом), а највећи број омашки бележимо у Читанци за седми разред основне школе чији је аутор О. Радуловић.

\section{7. Неки интерпункцијски знаци}

Систематично навођење свих интерпункцијских одступања од оригиналног текста у 15 уџбеника захтевало би посебан рад. Овде ћемо кроз неколико стихова, због ограниченог простора, приказати недоследност примене неких знакова интерпункције у читанкама. Одабрали смо 10 стихова од којих смо у првих пет проверавали употребу апострофа, наредна три стиха тичу се употребе запете, док смо у последња два стиха проверавали употребу цртице у споју презимена и имена епских јунака.

Читанке нису усаглашене по питању писања апострофа на месту где је глас $x$ изостављен. Тако наилазимо на двојаке приступе у различитим уџбеницима: Поараше дворе Јанковића и По'араше дворе Јановића / Тамо и је иаре потурчио и Тамо и' је чаре потурчио / Ја не мого од јада гледати и Ја не мого' од јада гледати / Већ побего саду винограду и Већ побего’ саду винограду. ${ }^{11}$

У готово свим средњошколским читанкама најчешће је, супротно извору, навођен апостроф у стиху Тамо и је царе потурчио (изузетак је читанка чији је аутор Д. Бабић). У другим стиховима које смо издвојили, проблем с апострофом имају скоро уједначено читанке за основну и за средњу школу. Сматрамо да је апостроф штампан иза сугласника $c$ из стиха Како с коња, таки за трпезу, посебно проблематичан у том смислу што би могао унети забуну у правописно знање ученика. Две читанке за седми разред (Klett: 2016. и Нови Логос: 2012) и једна за први (Нови Логос: 2014) иза овог гласа бележе апостроф.

\footnotetext{
${ }^{11}$ Навешћемо и остале стихове из песме у којима се апостроф (не)користи: Снае Јеле заборавит нећу и Сна'е Јеле заборавит нећу / Снао Јело, неношено злато и Сна'о Јело, неношено злато. Иста је ситуација и када је посреди изостављање вокала $u$ : Цар ће отић с Туриима у шетьу и Цар ће отић' с Туриима у шетьу, затим Снае Јеле заборавит нећу и Снае Јеле заборавит' нећу. Напоменимо и то да све читанке, у складу са изворним текстом, бележе апостроф у стиховима Ал'бедеси Смиљанић Илија / Од’ Илија двору бијеломе / Ево m' браца, господара мога! / Ал' говоре кићени сватови и Стан'те, браћо, кићени сватови!
} 
Проблем у бележењу запете најприсутнији је у стиху Ласно ћемо, ако јесмо људи. Већина основошколских читанки запету је заменила цртом. Такво правописно решење није неприхватљиво, али је у колизији са оригиналним текстом. Добар део средњошколских читанки у овом стиху након цезуре бележи запету, а има и оних у којима на овом месту изостаје било каква интерпункција. У готово свим средњошколским читанкама спорна је и запета после узвика у стиховима Ој Стојане, да мој мили брате! и О Илија, да мој мили брате.

У оригиналном тексту цртица стоји између презимена и имена епског јунака у три стиха: Заробише Смиљанић-Илију / Заробише Јанковић-Стојана и Господару, Јанковић-Стојане, док изостаје у стиховима: Ал' беседи Смиљанић Илија / Ал’ говори Јанковић Стојане / Нађе мајку Јанковић Стојане / Божио је Јанковић Стојане и Беседи им Јанковић Стојане (Караџић 1976: 123-127). Читанка за седми разред основне школе у издању Креативног центра не бележи цртицу у споју имена и презимена епских јунака. Таква је ситуација и у две средњошколске читанке - једној коју је објавила Едука, а другу, у издању Kletta, потписује двоје аутора.

Укупно смо констатовали 53 интерпункцијска пропуста у уџбеницима (нешто већи број у онима који су намењени старијим ученицима). Највише је грешака у Читании за први разред гимназија и средюих школа коју у издању Едуке потписује трочлани ауторски тим, док међу читанкама намењеним основцима највише пропуста броји она с насловом „Пут”, у издању Kletta. По једну неправилност (писање црте уместо запете) констатовали смо у 4 уџбеника за седми разред.

Неуједначеност интерпункције у читанкама веома је репрезентативна у стиху Јеси ли се уморила, мајко (Табела 2).

Табела 2. Интерпункција у стиху 'Јеси ли се уморила, мајко?'

\begin{tabular}{|l|l|l|}
\hline 1) & Јеси ли се уморила, мајко?” & у две читанке \\
\hline 2) & „Јеси ли се уморила, мајко?” & у четири читанке \\
\hline 3) & 'Јеси ли се уморила, мајко?” & у једној читанки \\
\hline 4) & Јеси ли се уморила, мајко?'” & у две читанке \\
\hline 5) & „Јеси ли се уморила, мајко?'” & у једној читанки \\
\hline 6) & 'Јеси ли се уморила, мајко?'” & у пет читанки \\
\hline
\end{tabular}




\section{8. Анализа збирних табела и 'рангирање' уџбеника'}

Укупно смо констатовали 192 неправилности у 15 уџбеника. Тај број је прилично равномерно подељен на читанке за седми разред основне школе (94 грешке) и први разред средње школе (98 грешака).

Највише је грешака које се односе на употребу знакова интерпункције, укупно 53, следе неправилности везане за испис гласа ,јат”, укупно их је 46, а забележили смо 43 омашке у навођењу облика речи. Локализацију текста ( у смислу навођења извора) доносе тек два уџбеника, док исправан наслов песме запажамо у само једној читанци. Даље, навели смо 10 примера у којима су гласови $x$ или $j$ дати погрешно, док је 7 стихова (у три уџбеника) наведено са мањком или вишком слогова. Читанке за седми разред основне школе имају највећи број огрешења у стиховима који се односе на рефлекс ,,јата”, док смо у уџбеницима намењеним средњошколцима уочили 30 грешака приликом навођења интерпункције (Табеле 3а и 3б).

Текст песме који је најприближнији оригиналном, у коме смо забележили 4 погрешке, штампан је у читанци која је, у издању Завода за уџбенике, некада била и једини уџбеник намењен основцима. Даље се по броју грешака међу читанкама за седми разред надовезују оне чији су издавачи Едука (5 грешака), Бигз (6 грешака) и Креативни центар (7 грешака). У уџбенику Новог Логоса из 2012. године регистровали смо 10 одступања од изворног записа песме. Укупно 12 неправилности избројали смо у тексту песме који је штампан у читанци „Пут” коју je издао Klett, док се грешка више уочава у читанци истог издавача, а која има наслов „Ризница речи”. Далеко највише неправилности, укупно 36, бележимо у Читанци за седми разред основне школе „Језик је дрво живота”. Далеко је већа осцилација погрешака у читанкама за седми разред, неголи у средњошколским и она се креће од 4 до 36 грешака (Табела 3a).

Када је реч о читанкама за први разред средње школе, бележимо 9 грешака у новијој читанци Завода за уџбенике, док смо у старијој, која има најдужи период употребе, констатовали једну погрешку више. Са 11 грешака следи читанка у издању Бигза, 13 смо избројали у читанци коју је издао Klett 2012. године, а једну грешку више у оној коју као издавач потписује Нови Логос. Укупно 15 пропуста садржи текст песме који је објављен у уџбенику у издању Kletta из 2019. године. Издваја се читанка са 20 пропуста коју у издању Едуке потписује трочлани ауторски тим. Укупан број погрешака у тексту песме код читанки намењених ученицима првог разреда креће се у распону од 9 до 20 (Табела 3б).

12 'Рангирање' уџбеника у овом раду искључиво се односи на то колико је у њима текст епске песме Ропство Јанковића Стојана штампан у складу са оригиналним записом, тј. колико од њега одступа. 


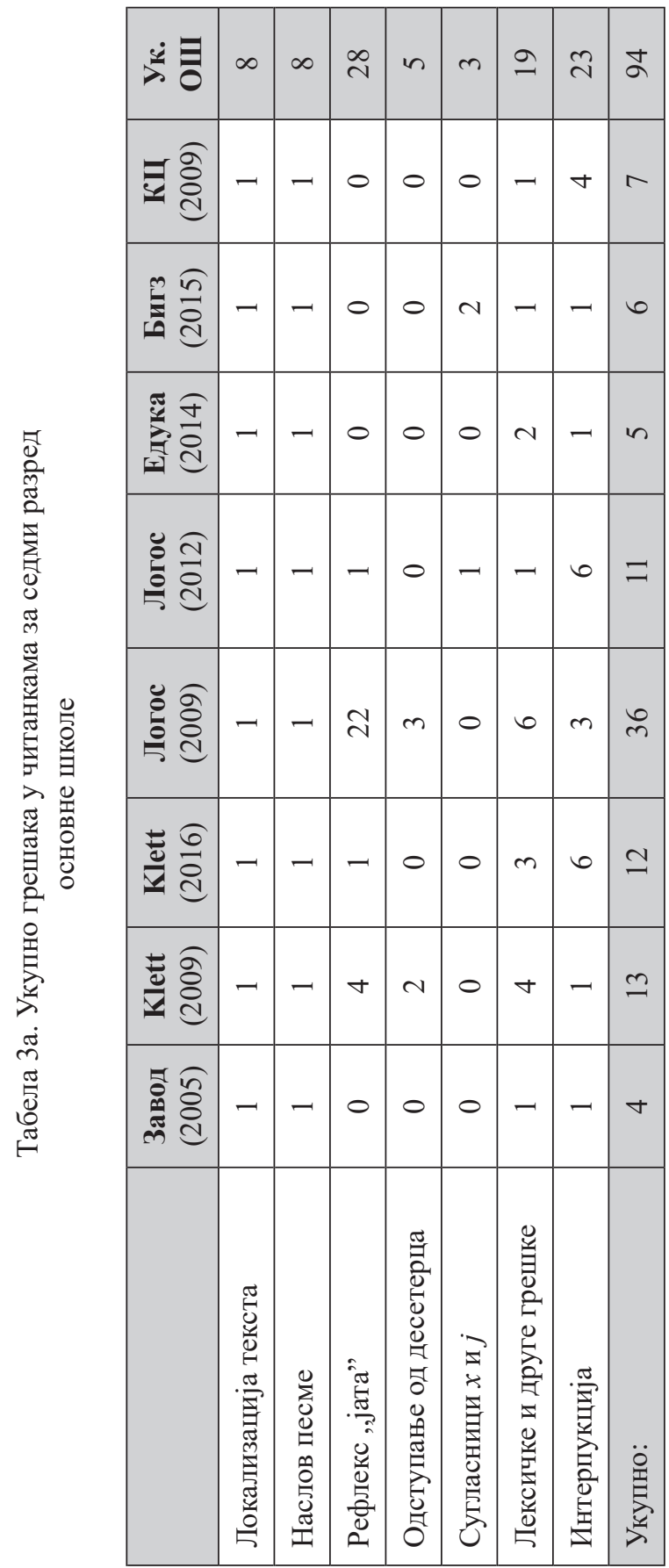




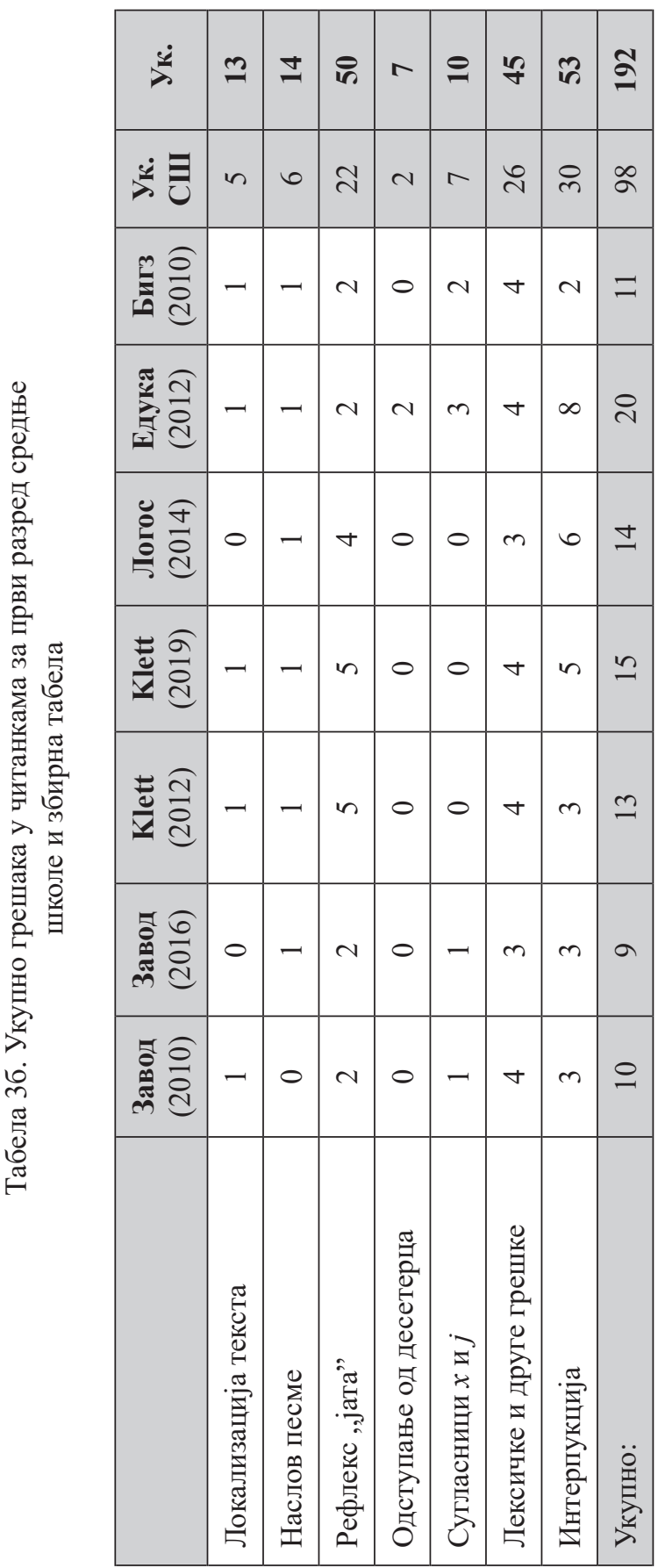


У свих 15 уџбеника које смо консултовали број погрешака креће се у распону од 4 до 36. Дакле, читанка која песму доноси најприближније оригиналном запису јесте она са најдужим стажом употребе у нашим школама. Реч је о уџбенику за седми разред основне школе чији је аутор Милка Андрић, а издавач Завод за уџбенике. Не охрабрује чињеница што чак у девет читанки бележимо двоцифрен број грешака. За оне у којима смо констатовали 20 или преко 30 грешака, с правом можемо поставити питање како су добили одобрење просветних власти.

\section{5. Закључак}

Истакли смо да читанка има посебно место у систему образовања и како је то уџбеник који мора да садржи поуздан текст књижевног дела. Међу уџбеницима које смо консултовали има неуједначености у броју неправилности. Најмање погрешака забележили смо у читанкама Завода за уџбенике, некада јединог издавача уџбеника код нас. За нешто више од једне деценије добили смо велики број читанки различитих приватних издавача, али су неке од њих веома дискутабилног квалитета. ${ }^{13}$ Текст књижевног дела у сваком од уџбеника морао би бити идентичан, у складу са оригиналом (извором). То не би требало да буде спорно, док би се о квалитету читанке као уџбеника могло расправљати на основу методичко-дидактичких решења у њој.

Приликом читања ове песме у првом разреду средње школе, пажљивији ученици могли би уочити извесне разлике у односу на текст исте песме коју су читали две године раније. Тешко је очекивати од наставника да ученицима предочи све грешке у тексту, јер би то одузело већи део наставног часа. Ипак, Милија Николић, најзначајнији методичар нашег предмета, сматра: „Ако уџбеник има и неких недостатака [...] ученици ће се упућивати да користе само његове добре стране, а слабости ће се отклањати скретањем пажње на њих, давањем приступачнијих и свеобухватних обавештења, избором бољих текстова [...] (Николић 1999: 57).

Сигурно је да већина грешака које смо регистровали у уџбеницима додатно утврђује ученичко незнање. Неке од њих могу бити збуњујуће чак и за наставнике. Анализирајући упитник који је садржао пет правописних питања (међу њима и оно које се односи на екавски и ијекавски изговор), В. Брборић констатује: „Резултати које су показали наставници у познавању екавског и ијекавског књижевног изговора (исписа) нису за похвалу” (Брборић 2011: 73).

Чињеница да ниједан од уџбеника које смо консултовали не доноси текст епске песме у складу са њеним оригиналним записом свакако је проблем који забрињава. Тај пропуст, осим аутора читанки, сносе и они који их потписују као рецензенти, али и просветне власти од којих су уџбеници одобрени за употребу.

${ }^{13}$ Сви коментари које смо у раду износили о уџбеницима односе се искључиво на чињеницу како су они донели текст епске народне песме Ропство Јанковића Стојана. 
Овакво стање тешко се може разумети. Ученици, без сумње, заслужују читанке без било каквих погрешака. То се односи на све уџбенике, а нарочито на оне из нашег предмета који у том смислу треба да буду узор.

\section{ЛИТЕРАТУРА ${ }^{14}$}

Брборић 2015: Вељко Брборић, Правопис и икола, Београд: Друштво за српски језик и књижевност Србије.

Брборић 2016: Вељко Брборић, О српском правопису, Београд, Друштво за српски језик и књижевност Србије.

Брборић 2019: Вељко Брборић, Муке око језика и правописа, Нови Сад: Прометеј.

Дашић 2016: Народна књижевност у наставним плановима и програмима, Београд: Друштво за српски језик и књижевност Србије.

Драгићевић и др. 2011: Рајна Драгићевић, Предраг Пипер и Марија Стефановић, Обратни асочијативни речник српскога језика, II део; од реакције ка стимулансу, Београд: Београдска књига и Службени гласник.

Ђурић 1990: Војислав Ђурић, Антологија народних јуначких песама, Београд: Српска књижевна задруга.

Караџић 1976: Вук Стефановић Караџић, Српске народне пјесме III, Београд: Просвета.

Милошевић Ђорђевић 2001: Српске народне епске песме и баладе, уредник и приређивач Нада Милошевић Ђорђевић, Београд: Завод за уџбенике.

Николић 1999: Милија Николић, Методика наставе српског језика и кюижевности, Београд: Завод за уџбенике и наставна средства.

Остојић, Вујичић 2000: Бранислав Остојић и Драгомир Вујичић, Речник (и)јекавизама српског језика, Подгорица, ЦИД.

Правопис 2010: Митар Пешикан, Јован Јерковић, Мато Пижурица, Правопис српскога језика, Нови Сад, Матица српска.

Речник МС 1967-1976: Речник српскохрватскога книжевног језика, I-VI, Нови Сад: Матица српска.

Самарџија 2005: Антологија епских народних песама, приредила и предговор написала Снежана Самарџија, Београд: Народна књига.

Сувајџић 2003: Епске народне песме о хајдуцима и ускоцима, приредио Бошко Сувајџић, Београд: Гутембергова галаксија.

${ }^{14}$ У списку литературе не наводимо уџбенике, тј. читанке које смо консултовали при писању рада. Оне су прецизно наведене у самом раду (Табела 1$)$. 
Vladimir B. Milojević

\title{
TEXT OF EPIK POEM SLAVERY OF JANKOVIC STOJAN IN PRIMARY AND SECONDARY SCHOOL READERS
}

\begin{abstract}
Summary
This paper examines text of epic poem Slavery of Janković Stojan in eight primary school and seven secondary school readers. In each textbook there are minor to significant deviations of the poem text from the original one (source). Mistakes that differ the poem from the original one by the title, transcription of the old vowel jat, deviation from decasyllabic meter, appearance of consonants $h$ and $j$, as well as lexical irregularities and punctuation mistakes are classified. Finally, the paper lists the textbooks in which with the smallest number of mistakes is recorded, as well as those with the largest number of mistakes.
\end{abstract}

Key words: national poem, reader, textbook, primary school, secondary school. 